\title{
URINARY DISORDERS AND BLADDER-BOWEL DYSFUNCTION IN CHILDREN: APPROACHES TO DIAGNOSIS, TREATMENT AND PREVENTION
}

Moiseev AB, Mironov AA ${ }^{凶}$, Kolbe OB, Vartapetova EE, Polunina W, Al-Sabunchi AA, Polunin VS, Buslaeva GN

Faculty of Pediatrics, Pirogov Russian National Research Medical University, Moscow

\begin{abstract}
Pediatric urinary disorders manifested as urinary incontinence, compelling urges to urinate, etc. remain an important problem of contemporary healthcare. In spite of being extensively covered in the literature, urinary disorders, including enuresis, still present a diagnostic challenge to the physicians of primary healthcare facilities. Based on the findings of our retrospective study that revealed discrepancies between referral and final diagnoses of pediatric urinary disorders, we give recommendations to both physicians of primary healthcare facilities and their inpatient care colleagues that will help them to arrive at the correct diagnosis of a urinary disorder or concomitant bladder-bowel dysfunction using the proposed diagnostic algorithm.
\end{abstract}

Keywords: children, urinary disorders, urinary incontinence, enuresis, encopresis, diagnosis and treatment, diagnostic difficulties

$\triangle$ Correspondence should be addressed: Andrey A. Mironov

Ostrovityanova 1, Moscow, 117997; 7190382@mail.ru

Recieved: 19.06.18 Accepted: 26.11.18

DOI: $10.24075 / \mathrm{brsmu} .2018 .067$

\section{НАРУШЕНИЯ МОЧЕИСПУСКАНИЯ И СОЧЕТАННЫЕ НАРУШЕНИЯ ФУНКЦИИ ТАЗОВЫХ ОРГАНОВ У ДЕТЕЙ: ПОДХОДЫ К ДИАГНОСТИКЕ, ЛЕЧЕНИЮ И ПРОФИЛАКТИКЕ}

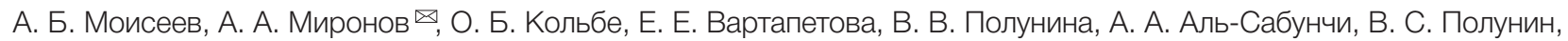
Г. Н. Буслаева

Педиатрический факультет, Российский национальный исследовательский медицинский университет имени Н. И. Пирогова, Москва

\begin{abstract}
Нарушения мочеиспускания у детей, проявляющиеся недержанием мочи, нестерпимыми позывами к микции и т. д., являются на сегодняшний день одной из актуальных проблем отечественного здравоохранения. Несмотря на широкое освещение данной проблематики в отечественныхи зарубежных источниках литературы, у врачей особенно первичного звена здравоохранения регулярно возникают сложности в правильной диагностике расстройств мочеиспускания, в том числе энуреза. По результатам ретроспективного анализа расхождения направительных диагнозов (из первичного звена здравоохранения) и заключительных клинических диагнозов у детей с нарушениями мочеиспускания даны рекомендации по правильной диагностике расстройств мочеиспускания, а также сочетанных нарушений функции тазовых органов; предложен алгоритм диагностики данных нарушений.
\end{abstract}

Ключевые слова: дети, нарушения мочеиспускания, недержание мочи, энурез, энкопрез, диагностика и лечение, трудности диагностики

$\checkmark$ Для корреспонденции: Андрей Анатольевич Миронов ул. Островитянова, д. 1, г. Москва, 117997; 7190382@mail.ru Статья получена: 19.06.18 Статья принята к печати: 26.11 .18 DOI: 10.24075/vrgmu.2018.067

In the past 25-30 years urinary disorders (UD) in children have been a matter of serious concern for pediatricians, nephrologists and urologists. Of all urinary conditions affecting the urodynamics of the lower urinary tract, UD are the most prevalent and comprise a wide range of disorders caused by the impaired storage or voiding function of the bladder [1, 3-6].

\section{Etiology and pathophysiology of urinary disorders in children}

UD have different causes, including stress, impaired innervation, neurosis, sudden changes in the psychosocial environment, genetics, and infections of the urinary tract. A lot of attention has been recently paid to the psychosomatic aspects of UD [2, 7-10].

Micturition is a complex reflex act of excreting the accumulated urine from the bladder through the urethra; it is the final stage of eliminating urine from the body. In newborns, infants and toddlers the bladder voids involuntary [4, 11, 12]. In older children, uncontrolled micturition signals the delayed development of the mature reflex and often results from late toilet training. Children are able to exert partial daytime control over their bladder at 2-3 years and achieve full dryness during the day by the age of 3-4 once their micturition centers in the brain and the spinal cord have matured and the adult myelination pattern of peripheral nerve fibers has been attained. By the age of $4-5$ years children are able to stay dry through the night; the girls develop this ability earlier than boys. Full bladder control ensures adequate socialization. However, the mature micturition reflex is fully formed only when the child has learnt to voluntarily control the external periurethral sphincters, hold urine during the day and at night and intentionally halt its flow [3, 4, 8, 13].

Parental behavior plays a critical role in the formation of voiding habits. Parents are advised to start teaching their child good hygiene and introduce potty training at the age of 
15-18 months encouraging socially acceptable behavior. The child quickly gets the hang of using the potty through positive reinforcement. Everything matters in toilet training, even the shape of the potty. Russian and foreign pediatricians usually recommend to start training at about 18 months [14]. The potty should have a simple shape, a solid color, a comfortable seat, be made of certified and easy-to-wash materials. Toy- or chairshaped all-in-one potties in flashy colors should be avoided to prevent the child from associating the potty with playing, eating or sleeping $[10,15,16]$. The child gradually develops control over their bladder and bowel and feels satisfaction of becoming master of their own body. In this period the parents should be reassuring and patient, provide a positive feedback and create a friendly atmosphere in the family. Even the slightest stress or punishment for being wet or soiled can lead to diurnal/nocturnal enuresis, fecal incontinence and/or chronic constipation in 70 to $75 \%$ of children $[1,2,10,17]$. Attaining continence is a milestone in the social, mental and psychosexual development of the child and a direct outcome of parental efforts [2, 17-19].

In the past 10 to 15 years absorbent hygiene products, such as disposable diapers, fitted briefs, pads, etc. have become increasingly popular among the parents of incontinent children $[15,18]$. They are convenient, practical and make the life of such children more comfortable. But in fact, their continuous use aggravates the situation. The child gets used to being dry while being incontinent and stops controlling their bladder at all. This has a profound impact on the child's personality because delayed adaptation to social norms inevitably leads to immaturity. Although the materials diapers are made from are "breathable" and meant to prevent the genital area from overheating, their continuous use can still pose a threat to male health because the genitals stay too warm under a diaper [8, $11,15,20]$.

Based on our personal observations and the published literature, we recommend that parents of incontinent children should gradually eliminate diapers or other absorbent products as the first step towards recovery. It can be a real challenge because ironically it is usually the parent and not the child who benefits from diapers. Parents will often go in denial thinking that as long as the child stays dry wearing a diaper both at night and during the day there is no real problem; still the child keeps passing urine involuntary unable to control the process. It can be much harder to persuade the parents to stop using diapers than to rehabilitate the child [12, 15, 21, 22].

Some research works in neurophysiology and urology link UD and impaired urodynamics to the developmental delay of higher brain centers involved in the autonomic regulation of the lower urinary tract. Substantial contribution to UD is made by the hypofunction of the hypothalamus-pituitary complex. Electroencephalography often detects abnormal electrical activity in the brain of incontinent children. Hypertonia and hyperactive sympathetic and parasympathetic divisions of the autonomic nervous system are another common cause of daytime incontinence. Disturbances in the regulation of the sleep/wake cycle by the limbic system and reticular formation and abnormal production of adrenal, growth or sex hormones can also result in UD $[1,4,8,10]$.

Some authors have demonstrated that UD severity is determined by the severity and character of nervous system pathology. Children who receive adequate treatment aimed at restoring the normal function of higher brain centers involved in the autonomic regulation of micturition make a complete recovery from incontinence. This is key to the effective therapy of UD in children $[5,9,17,23]$.
It has been established that about $90 \%$ of UD are functional meaning that they can be managed using a wide arsenal of effective conventional medical and nonmedical therapies, as well as psychological techniques. Importantly, though, neurological deficits that suppress maturation of centers exerting control over micturition resolve at different rates in different children. Therefore, treatment should be tailored to an individual patient to produce the desired outcome [1, 11, 24, 25].

Clinical manifestations of UD are very diverse: from different combinations of diurnal/nocturnal incontinence patterns to changes in the frequency or volume of the voided urine to urges to urinate. The most common UD are the urge syndrome (US) manifested as pollakiuria, a compelling urge to urinate and urge incontinence and enuresis. Its prevalence in children is estimated to reach $10 \%$. In patients with renal and urologic diseases US prevalence is as high as $50-60 \%$. Incontinence is not an exclusively pediatric condition; it also affects between $1-2 \%$ and $5-25 \%$ of adults $[4,13,16,25]$.

There is still an ambivalence about passing urine and stools felt by the modern society that often interferes with timely diagnosis and treatment of incontinence. On the one hand, people are constantly reminded that micturition and defecation are natural important aspects of human existence like sleeping, eating, etc. On the other hand, they are perceived as dirty or disgraceful, and discussing them (even with a physician) is believed to be inappropriate and vulgar. They are a taboo subject, an embarrassing issue that should be kept in secret. Therefore, patients do not realize that bladder or bowel disturbances they may be experiencing are a sign of pathology and do not rush to seek medical advice until it becomes a real problem. This explains the disparity in the results of randomized studies that report incontinence in 1-25\% of adults caused by ethical and psychosocial issues: people find it difficult to tell the doctor that they have "accidents" [8, 13, 15, 23].

Enuresis is leakage of urine during sleep (more often at night time than during the day) at the age when full control over urination is expected to be achieved. According to Russian authors, full control over bladder should be attained by the age of 5 years. Foreign authors believe that 6 years is the right time. Enuresis is estimated to affect $2.3-30 \%$ of children between $5-6$ and 15 years of age; of them the proportion of 5-year-old children is 15-20\%; 6-8-year-old, $7-12 \%$, and $15-18$-year-old, $1.5-4 \%$. In the past, the medical community (and ICD-10) distinguished between primary and secondary enuresis. Primary means that the child never had control of their bladder, secondary means that there was a period of dryness before the child became incontinent. At present, more attention is paid to how the condition progresses [1, 4, 19, 26]. The International Children's Continence Society (ICCS; 2011) has proposed to classify enuresis into monosymptomatic and nonmonosymptomatic. Monosymptomatic enuresis is involuntary voiding of discrete amounts of urine during nighttime sleep in the absence of daytime urinary symptoms suggestive of storage/voiding dysfunction of the bladder. Nonmonosymptomatic enuresis is a combination of nocturnal and diurnal wetting. Diurnal incontinence is wetting at daytime when the child is awake (at night the child stays continent). The reported prevalence of mono- and nonmonosymptomatic enuresis in children varies. Some authors estimate that monosymptomatic enuresis is found in $43 \%$ of children whereas nonmonosymptomatic, in $57 \%$ of children; others report that monosymptomatic enuresis occurs in $68.5 \%$ patients whereas nonmonosymptomatic, in $31.5 \%[3,7,8,11]$. According to our observations, monosymptomatic enuresis strikes $24 \%$ of children and 
nonmonosymptomatic, 58\%. Diurnal incontinence occurs in $18 \%$ of patients.

Agitation and stress are often accompanied by frequent urination, which in turn can trigger or aggravate incontinence. Usually, nocturnal enuresis can be kept secret, except when the child has to stay in other people's company round the clock. In contrast, involuntary urination at daytime often occurs in public places and is more emotionally traumatic for the child $[2,10,18,25]$.

Today, UD still remain a pressing concern for healthcare practitioners. The condition can be aggravated by social stereotypes, family attitude and the lack of medical awareness. In the majority of cases, voiding dysfunction is perceived as a shameful situation, lack of hygiene skills, "bad manners" or even a sign of mental retardation instead of being considered a serious health condition that should be reported to the doctor and treated adequately. Urinary disorders are usually swept under the carpet or ignored by parents who consider incontinence to be a "unique" feature of their child and a variation of the norm or punish the child or wait until the child will outgrow it and therefore do not seek medical advice [15, 20, 21].

Urinary disorders such as incontinence, pollakiuria, or frequent urges to urinate, are not life-threatening but have serious social implications. They significantly impair the psychological development and physical activity of a child, leave them feeling handicapped, instill guilt, prevent them from integrating into the society, and negatively affect the quality of life of the whole family $[8,22,25]$. Problems with peers, academic underachievement and family conflicts are common consequences of UD. About $30 \%$ of UD result in recurrent cystitis, vesicoureteral reflux, ureterohydronephrosis, pyelonephritis and subsequent nephrosclerosis or renovascular hypertension. UD and bladder-bowel dysfunctions are often accompanied by pelvic vein incompetence and weakness of pelvic floor muscles. In adults these conditions can cause sexual dysfunction (impotence, premature ejaculation or infertility in men and anorgasmia, vaginismus, prolapse, or miscarriage in women). Having an onset in childhood, UD and BBD debilitate economically active population groups and deteriorate their quality of life $[8,23,27]$.

\section{Difficulties in the diagnosis and treatment of urinary and defecation disorders in children}

Extensive observation of our patients with UD has revealed a few negative trends in the primary healthcare system (mostly organizational problems) resulting in the delayed or misdiagnosis of UD and concomitant pelvic floor dysfunction in children.

Table 1. Symptoms of bladder-bowel dysfunction in the examined children
In the past 20 years approaches to the diagnosis, treatment and rehabilitation of patients with functional UD and bowel comorbidities have changed dramatically both in Russia and abroad. Medical treatment has been largely replaced with nonmedical or combination therapies. Russian physicians have a great variety of treatment options at their disposal including anticholinergic drugs, surgical interventions to alleviate the symptoms (these are rarely used in children), physical therapy, acupuncture, psychotherapy, self-hypnosis affirmations, urotherapy (bladder re-education), and pelvic floor biofeedback therapy (BFT). Each of these effective techniques is actively promoted, making it hard for a physician to choose one the patient will benefit from the most. The first-line treatment of incontinence includes nonmedical and noninvasive interventions. They are popular among physicians due to their good diagnostic and rehabilitation potential. Among such treatment options is electromyographic biofeedback therapy, which is, in essence, computer-assisted pelvic floor muscle training (Kegels) [16, 28-30]. Nonmedical therapy also includes bladder re-education, scheduled voiding/defecation, psychotherapy and wetting alarms. If nonmedical modalities are ineffective, medications and physical therapy are introduced to the regimen alone or in combination [1, 8, 24, 26].

Treatment and rehabilitation of patients with UD will be ineffective if the diagnosis is inaccurate; therefore, it is important to discuss the problem of accurate diagnosis in detail. The lower urinary tract and the distal regions of the gastrointestinal tract are supported by the pelvic diaphragm; they share blood vessels and innervation and exert similar functions of storing, holding and excreting urine or feces. Disorders of the lower urinary tract (diurnal or nocturnal incontinence, US, etc.) and the intestinal tract (constipation, soiling) can co-exist aggravating each other $[8,20,23,27]$. Patients with concomitant disorders of the lower urinary tract and the gastrointestinal system are often referred to in the foreign literature as having bladder-bowel dysfunction (BBD). This nosology is rarely seen in the medical records of Russian hospitals. Transition from the diagnostic approach based on the symptoms of one organ system, such as the urinary or gastrointestinal tract, to functional, which relies on the assessment of the integrated contribution of organs constituting different systems, is an important prerequisite for the accurate diagnosis and successful treatment of BBD. This interdisciplinary approach allows doctors with narrow specialist expertise, such as pediatricians, nephrologists, urologists, gastroenterologists, proctologists, neurologists, etc., to have a broader perspective of the problem, establish a timely and accurate diagnosis independent of each other, and choose an adequate treatment regimen for a patient with BBD.

\begin{tabular}{|l|c|c|c|c|c|c|}
\hline \multirow{2}{*}{ Symptoms of BBD } & \multicolumn{2}{|c|}{ Boys } & \multicolumn{2}{|c|}{ Girls } & \multicolumn{2}{|c|}{ Total } \\
\cline { 2 - 6 } & Abs. number & $\%$ & Abs. number & $\%$ & Abs. number & $\%$ \\
\hline Enuresis + US + chronic constipation + encopresis) & 93 & 4.6 & 161 & 7.8 & 254 & 12.4 \\
\hline Enuresis + chronic constipation + encopresis & 147 & 7.2 & 53 & 2.6 & 200 & 9.8 \\
\hline Enuresis + US + encopresis & 53 & 2.6 & 67 & 3.3 & 120 & 5.9 \\
\hline Enuresis + encopresis & 40 & 1.9 & 14 & 0.7 & 54 & 2.6 \\
\hline Enuresis + chronic constipation & 27 & 1.3 & 12 & 0.6 & 39 & 1.9 \\
\hline Enuresis + US + chronic constipation & 12 & 0.6 & 15 & 0.7 & 27 & 1.3 \\
\hline US + chronic constipation + encopresis & 28 & 1.4 & 25 & 1.2 & 53 & 2.6 \\
\hline US + chronic constipation & 3 & 0.1 & 49 & 2.4 & 52 & 2.5 \\
\hline US + encopresis & 13 & 0.6 & 28 & 1.4 & 41 & 2 \\
\hline Total & 416 & 20.4 & 424 & 20.7 & 840 & 41.1 \\
\hline
\end{tabular}


The importance of the interdisciplinary approach is confirmed by the data obtained during the examination and treatment of 2,043 children aged 7 to 18 years who presented with nonorganic UD in 2003 through 2013 (881 boys and 1,162 girls, mean age of $9.8 \pm 3.4$ years, $p=0.05)$. The nonorganic (functional) etiology of UD was confirmed by the complete examination of the urinary system. The patients constituted 3 age groups: $7-10$ years, $11-14$ years and 15-18 years; each of the groups was divided into the subgroup of boys and the subgroup of girls. In 840 children (41.1\%), of whom 416 (20.4\%) were boys and 424 (20.7\%) were girls, BBD manifested itself as a combination of enuresis, US, stress incontinence, chronic constipation, and encopresis (soiling) (Table 1).

Bladder-bowel dysfunction was prevalently manifested as enuresis (34\%), chronic constipation (30.6\%), US (26.8\%), and a combination of chronic constipation and encopresis (24.8\%).

The data demonstrating the relationship between a BBD symptom and a child's age are also interesting. BBD was manifested as concomitant enuresis, US, and encopresis predominantly in boys and girls between 7 and 11 years of age and also in girls aged 11-14 and 15-18. Co-existent symptoms of enuresis, US, encopresis, and chronic constipation were observed in all age groups, except for the boys between 15 and 18 years. A combination of enuresis, US and chronic constipation only occurred in children between 7 and 10 years, whereas enuresis + soiling occurred in children between 11 and 14 years. Concomitant enuresis, encopresis and chronic constipation were diagnosed in children aged $7-10$ and in boys aged 11-14. US and comorbid encopresis were observed in children aged $7-10$ and in girls of 11-14. A combination of US and chronic constipation occurred only in girls in all age groups, while US, soiling and chronic constipation were coexistent in boys between 7 and 10 years of age and in girls aged 11 to 14 years. The older the children were, the rarer and less varied the BBD symptoms became.

While conducting the retrospective analysis of pediatric medical histories, we found that the diagnosis established at a primary care facility that eventually referred the child to an inpatient facility was not always concordant with the final clinical diagnosis (Table 2).

The primary diagnosis of enuresis was established in $49.7 \%$ children, whereas its actual incidence was 2.2. times lower: it was verified only in $23 \%$ of the admitted inpatients $(p<0.01)$. Physicians of primary care facilities were often unable to notice other symptoms of urinary and defecation disorders. As a result, some children did not have a verified diagnosis before they were admitted to hospital: $20.9 \%$ of them were diagnosed with a neurogenic dysfunction of the bladder of unspecified etiology. Isolated US was not specified in the referral diagnosis, but as a final diagnosis it was established in $188(9 \%)$ of the admitted patients. At primary care facilities BBD was diagnosed in $29.4 \%$ vs $41.1 \%$ of in-hospital diagnoses ( $p<0.01$ ), meaning that its actual incidence was 1.4 times higher. The obtained data indicate that physicians at primary care facilities tend to overdiagnose enuresis and underdiagnose US and BBD in children with urinary and defecation disorders. Besides, many doctors erroneously think that any urinary disorder or incontinence is a case of enuresis. However, Russian authors and ICCS guidelines (2011) define enuresis as involuntary voiding of urine during sleep. In our retrospective study, urinary disorders, both isolated and concomitant with defecation disorders, were often mistaken for enuresis, which naturally resulted in the wrong treatment strategy and poor treatment outcome.

We believe that there are two major reasons underlying over-, under- and misdiagnosis of urinary disorders and BBD: doctors working at primary care facilities do not have sufficient medical knowledge of these conditions and are too pressed for time to take full medical history and analyze the presented problem. Patients are referred to different specialists again and again but doctors cannot arrive at the right diagnosis, therefore, treatment is delayed. Unfortunately, doctors often prescribe wrong treatments that do not help the patient, which causes frustration both in parents and their child as well as dissatisfaction with the quality of healthcare.

To improve the situation, physicians should be encouraged to maintain their certification. Information about pediatric UD and BBD should be included in the syllabus of professional training courses. At present, primary care facilities focus on improving the availability and quality of medical care. Better life quality for children is one of top priorities of modern healthcare that can be achieved, among other things, through timely diagnosis of urinary and defecation disorders. Adequate treatment will facilitate children's social adaptation allowing them to cope with the challenges of the current economic situation. Today patients are free to choose a medical care facility they want to seek advice at by channeling their health insurance payments to the preferable clinic. This stimulates competition between and among private and state-funded facilities.

The schematic algorithm below was developed by the authors to help doctors working at inpatient and primary care facilities make a successful clinical diagnosis of UD and BBD in children (Fig. 1).

\section{CONCLUSIONS}

UD and BBD have various causes. To establish an accurate diagnosis of UD or BBD, a multidisciplinary approach should be applied. It is important to rule out BBD and organic pathology in children with urinary incontinence prior to starting therapy. The first-line treatment of UD/BBD includes electromyographic biofeedback therapy, urotherapy, scheduled voiding/

Table 2. Concordance of the referral and final clinical diagnoses

\begin{tabular}{|c|c|c|c|c|}
\hline \multirow{2}{*}{ Diagnosis } & \multicolumn{2}{|c|}{ Referral } & \multicolumn{2}{|c|}{ Final } \\
\hline & Abs. number & $\%$ & Abs. number & $\%$ \\
\hline Enuresis (isolated) & 1015 & 49.7 & 470 & 23 \\
\hline Urge syndrome (isolated) & 0 & 0 & 184 & 9 \\
\hline Enuresis and urge syndrome & 0 & 0 & 268 & 13.1 \\
\hline Enuresis and stress urinary incontinence & 0 & 0 & 198 & 9.7 \\
\hline Infrequent micturition & 0 & 0 & 83 & 4.1 \\
\hline Concomitant bladder and bowel dysfunctions & 601 & 29.4 & 840 & 41.1 \\
\hline Neurogenic dysfunction of the bladder of unspecified etiology & 427 & 20.9 & 0 & 0 \\
\hline Total & 2043 & 100 & 2043 & 100 \\
\hline
\end{tabular}




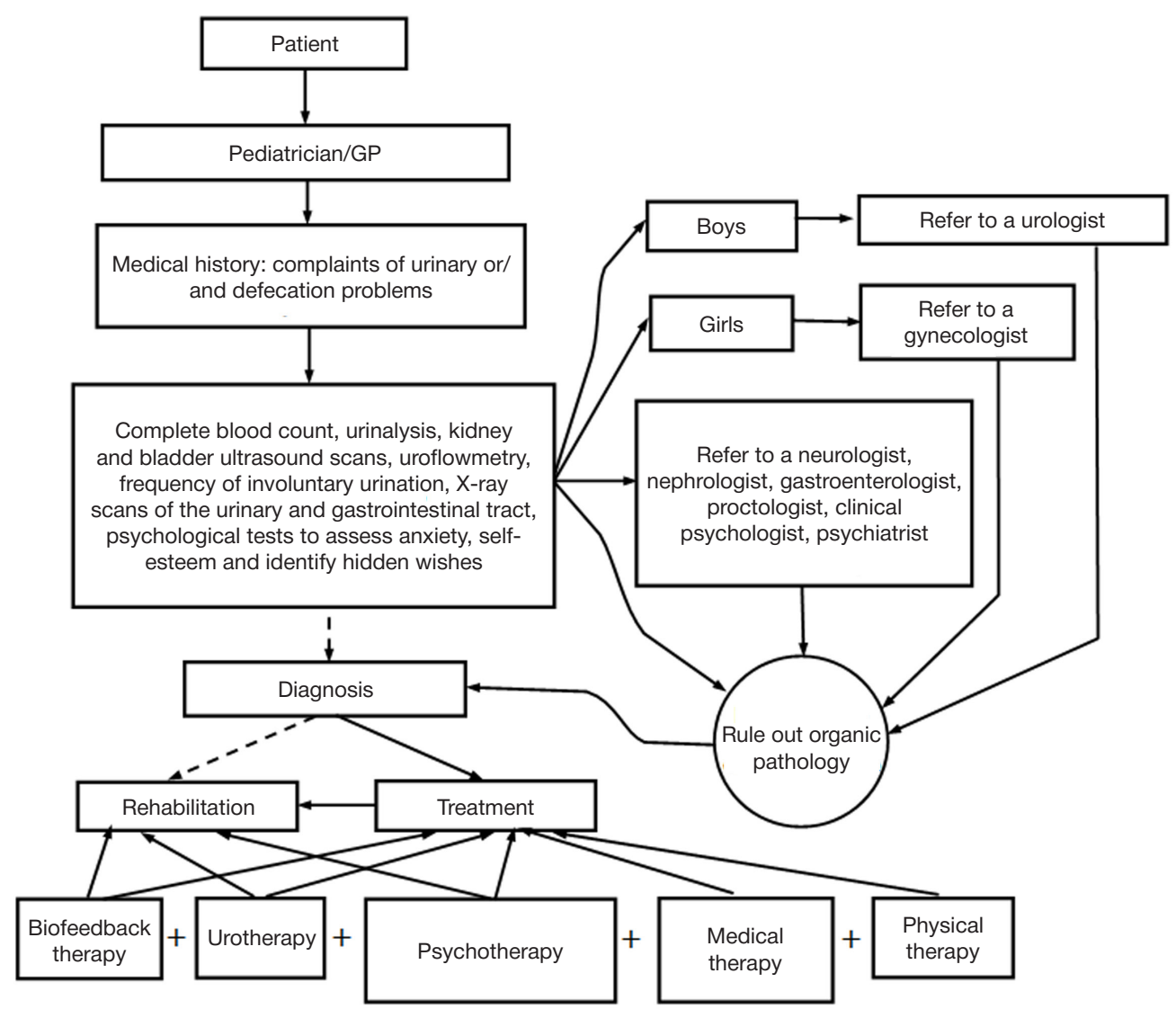

Fig. 1. The schematic algorithm for the diagnosis of urinary disorders and bladder-bowel dysfunction in children

defecation, psychotherapy, and the use of wetting alarms. Parents are advised to gradually eliminate diapers, fitted briefs or other absorbent hygiene products. If the first-line therapy does not produce the desired effect, medications, physical therapy, or a combination of both should be started Treatment and rehabilitation outcomes can be significantly improved through maintaining the continuity of care for patients transferred from the outpatient to inpatient setting. To solve the problem of delayed diagnosis in children with UD/BBD, the following measures are proposed from the experience of
Russian healthcare practitioners and their foreign colleagues: 1) improving the quality of professional education and training; 2) increasing appointment time; 3) strengthening laboratory capacities affiliated with primary healthcare facilities and creating more hospital beds in day treatment units; 4) merging outpatient and inpatient facilities into bigger health centers that provide diagnostic, treatment and rehabilitation services to patients with UD and BBD. These measures can significantly improve diagnostic accuracy and treatment outcomes in children with UD and BBD.

\section{References}

1. Otpushchennikova TV. Sovremennye metody lecheniya enuresa pri narusheniyah mocheispuskaniya u detey. Byulleten meditsinskih Internet-konferetsiy (ID: 2015-06-1276-R-5300) 2015; 5 (6): 918-22.

2. Morozov SL, Dlin W, Slonimskaya MM. Psikhosotsial'nye aspekty narusheniy mocheispuskaniya $u$ detey. Rossiyskiy vestnik perinatologii i pediatrii. 2015; (5): 92-5.

3. Morozov SL, Dlin W, Guseva NB, Slonimskay MM, Tonkih EV Sovremennyy podhod $k$ terapii monosiptomnogo enureza $u$ detey. Rossiyskiy vestnik perinatologii i pediatrii. 2015; (4): 210-1.

4. Papayan AV, Savenkova ND. Klinicheskaya nefrologiya detskogo vozrasta. SPb.: Levsha, 2008; 600 s.

5. Dubina SP, Evtushenko OS, Evtushenko SK. Diagnostika i terapiya enureza u detey (nauchnyy obzor i lichnye nablyudeniya). Mezhdunarodnyy nevrologicheskii zhurnal. 2013; 6 (60): 114-20.

6. Fagundes SN, Lebl AS, Azevedo-Soster L, Sousa E Silva GJ, Silvares EF, Koch VH. Monosymptomatic noctural enuresis in pediatric patients: muitidisciplinary assessment and effects of therapeutic intervention. Pediatr Nephrol. 2017; 32 (5): 843-51.

7. Jain S, Bhatt GC. Advances in the management of primary monosymptomatic noctural enuresis in children. Pediatr Int Child

Healt. 2016; 36 (1): 7-14.

8. Bauer S, Neveus T, Ostin P. Diagnostika i lecheniye detey s rasstroystvami mocheispuskaniya. Materialy Rossiyskogo simpoziuma Mezhdunarodnogo obshchestva po problemam nederzhaniya mochi u detey i Rossiyskoy assotsiatsii detskikh khirurgov, 18-20 oktyabrya. M., 2011; 154 s.

9. Studenikin VM, Tursunkhuzhayeva SSh, Shelkovskiy VI., Pak LA. Nochnoy enurez $v$ neyropediatrii: sovremennyye podkhody $k$ lecheniyu. Effektivnaya farmakoterapiya. Pediatriya. 2012; (4): 44-9.

10. Gulisiano M, Domini C, Capelli M, Pellico A, Rizzo R. Important of neuropsychiatric evalution in children with primary monosymptomatic enuresis. J Pediatr Urol. 2017; 13 (1): 1-6.

11. Franco I. Functional bladder problems in children: pathophysiology, diagnosis and treatment. Pediatr Clin North Am. 2012; 59 (4): 783-817.

12. Santos JD, Lopes RI, Koyle MA. Bladder and bowel dysfunction in children: An update on the diagnosis and treatment of a common, but underdiagnosed pediatric problem. Can Urol Assoc J. 2017; (11): 64-72.

13. Fernandez-lbeta M, Ayuso-Gonzalez L. Dysfunctional voiding in 
pediatrics: a review of pathophysiology and current treatment modalities. Curr Pediatr Rev. 2016; 12 (4): 291-300.

14. URL: http://www.pediatr-russia.ruypediatr/press/potty/article...html (data obrashcheniya 24.11.2018).

15. Denisova OI, Namazova-Baranova LS, Karkashadze GA, Gevorkyan AK, Maslova Ol. i dr. Formirovanie tualetnyh navykov u detey iz semey obshchey populyatsii i semey s vysokim sotsial'no-economicheskim statusom. Sravnitel'noe issledovanie. Pediatricheskaya farmacologiya. 2015; 12 (2): 156-65.

16. Schultz-Lampel D, Steuber C, Hoyer PF, Bachmann CJ, MarschallKehrel D, Bachmann H. Urinary incontinence in children. Dtsch Arztebl Int. 2011; 108 (37): 613-20.

17. von Gontard A, Baeyens D, Van Hoecke E, Warzak WJ, Bachmann C. Psychological and psychiatric issues in urinary and fecal incontinence. J Urol 2011; (4): 1432-36.

18. Pugachev AG, Romikh W, Alferov SN. Klinicheskiye osobennosti funktsional'nykh narusheniy mocheispuskaniya $\mathrm{V}$ detskom vozraste. Lechashchiy vrach. 2004; (9): 32-5.

19. Neveus T. Nocturnal enuresis - theoretic background and practical guidelines. Pediatr Nephrol. 2011; 26 (8): 1207-14.

20. Neveus T, Sillen U. Lower urinary tract function in childhood: normal development and common functional disturbances. Acta Physiol. (Oxf). 2013; 207 (1): 85-92.

21. Queiroz Machado V, Monteiro A, Pecanha A, Garcez da Foseca E. Slow transit constipation and lower urinary tract dysfunction. $J$ Pediatr Urol. 2015; 11 (6): 3571-5.

22. Ignatyev RO, Geld VG, Guseva NB, Bozhendayev TL. Diagnostika narusheniy mocheispuskaniya u detey: vsë li delayem pravil'no? Rossiyskiy vestnik detskoy khirurgii, anesteziologii i reanimatologii. 2014; 4 (3): 39-45.
23. Nurko S, Scott SM. Coexistence of constipation and incontinence in children and adults. Best Pract Res Clin Gastroenterol. 2011; 25 (1): 29-41.

24. Nesterenko OV, Goremykin VI. Kompleksnyy podhod k lecheniyu pervichnogo monosimptomnogo nochnogo enuresa u detey. Lechashchiy vrach. 2013; (9): 70-3.

25. Zakharova IN, Mumladze EB, Pshenichnikova II. Enurez v praktike pediatra. Meditsinskiy sovet. 2017; (1): 172-9.

26. Morozov VI, Ayupova VA, Salikhova LT. Lecheniye razlichnykh klinicheskikh form enureza u detey. Prakticheskaya meditsina. 2016; 7 (99): 77-80.

27. Nikitin SS, Ignatyev RO, Guseva NB, Ryzhov EA, Fomenko OYu, Ponomarëva TN. Vozmozhnosti povysheniya kachestva zhizni detey $s$ sochetannymi rasstroystvami mocheispuskaniya defekatsii pri unifikatsii metodov diagnostiki i lecheniya. Detskaya khirurgiya. 2014; (5): 8-12.

28. Belyaeva NA, Shmatok DO, Blinov EV, Guliev AG, Igumenov IA Terichev AE. Opyt primeneniya biologicheskoy obratnoy svyazi v lechenii detey s razlichnymi vidami enureza. Zdorov'e i obrazovanie v XXI veke. 2016; 18 (11): 21-3.

29. Ebilogiu T, Kaya E, Körpü B, Topuz B, Irkilata HC, Kibar Y. Biofeedback as a first-line treatment for overactive bladder syndrome refractory to standard urotherapy in children. J Pediatr Urol. 2016; 12 (5): 2901-7.

30. Sansak EB, Akbaș A, Kurt Ö, Alan C, Ersay A R. The effectiveness of biofeedback therapy in children with monosymptomatic enuresis resistant to desmopressin treatment. 2016; 41 (4): $278-84$

\section{Литература}

1. Отпущенникова Т. В. Современные методы лечения энуреза при нарушениях мочеиспускания у детей. Бюллетень медицинских Интернет-конференций (ID: 2015-06-1276-R5300) 2015; 5 (6): 918-22.

2. Морозов С. Л., Длин В. В., Слонимская М. М. Психосоциальные аспекты нарушений мочеиспускания у детей. Российский вестник перинатологии и педиатрии. 2015; (5): 92-5.

3. Морозов С. Л., Длин В. В., Гусева Н. Б., Слонимская М. М., ТонкихЕ. В. Современный подход ктерапии моносимптомного энуреза у детей. Российский вестник перинатологии и педиатрии. 2015; (4): 210-1.

4. Папаян А. В., Савенкова Н. Д. Клиническая нефрология детского возраста. СПб.: Левша, 2008; 600 с.

5. Дубина С. П., Евтушенко О. С., Евтушенко С. К. Диагностика и терапия энуреза у детей (научный обзор и личные наблюдения). Международный неврологический журнал. 2013; 6 (60): 114-20.

6. Fagundes SN, Lebl AS, Azevedo-Soster L, Sousa E Silva GJ, Silvares EF, Koch $\mathrm{VH}$. Monosymptomatic noctural enuresis in pediatric patients: muitidisciplinary assessment and effects of therapeutic intervention. Pediatr Nephrol 2017; 32 (5): 843-51.

7. Jain S, Bhatt GC. Advances in the management of primary monosymptomatic noctural enuresis in children. Pediatr Int Child Healt. 2016; 36 (1): 7-14.

8. Бауэр С., Невеус Т., Остин П. Диагностика и лечение детей с расстройствами мочеиспускания. Материалы Российского симпозиума Международного общества по проблемам недержания мочи у детей и Российской ассоциации детских хирургов, 18-20 октября. М., 2011. 154 с.

9. Студеникин В. М., Турсунхужаева С. Ш., Шелковский В. И., Пак Л. А. Ночной энурез в нейропедиатрии: современные подходы к лечению. Эффективная фармакотерапия. Педиатрия. 2012; (4): 44-9.

10. Gulisiano M, Domini C, Capelli M, Pellico A, Rizzo R Important of neuropsychiatric evalution in children with primary monosymptomatic enuresis. J Pediatr Urol. 2017; 13 (1): 1-6.

11. Franco I. Functional bladder problems in children: pathophysiology,

diagnosis and treatment. Pediatr Clin North Am. 2012; 59 (4): 783-817.

12. Santos JD, Lopes RI, Koyle MA. Bladder and bowel dysfunction in children: An update on the diagnosis and treatment of a common, but underdiagnosed pediatric problem. Can Urol Assoc J. 2017; (11): 64-72.

13. Fernandez-lbeta M, Ayuso-Gonzalez L. Dysfunctional voiding in pediatrics: a review of pathophysiology and current treatment modalities. Curr Pediatr Rev. 2016; 12 (4): 291-300.

14. URL: http://www.pediatr-russia.ru'pediatr/press/potty/article...html (дата обращения 24.11.2018)

15. Денисова О. И., Намазова-Баранова Л. С., Каркашадзе Г. А., Геворкян А. К., Маслова О. И., и др. Формирование туалетных навыков у детей из семей общей популяции и семей с высоким социально-экономическим статусом. Сравнительное исследование. Педиатрическая фармакология. 2015; 12 (2): 156-65.

16. Schultz-Lampel D, Steuber C, Hoyer PF, Bachmann CJ, MarschallKehrel D, Bachmann H. Urinary incontinence in children. Dtsch Arztebl Int. 2011; 108 (37): 613-20.

17. von Gontard A, Baeyens D, Van Hoecke E, Warzak WJ, Bachmann C. Psychological and psychiatric issues in urinary and fecal incontinence. J Urol. 2011; (4): 1432-36.

18. Пугачев А. Г., Ромих В. В., Алферов С. Н. Клинические особенности функциональных нарушений мочеиспускания в детском возрасте. Лечащий врач. 2004; (9): 32-5.

19. Neveus T. Nocturnal enuresis - theoretic background and practical guidelines. Pediatr Nephrol. 2011; 26 (8): 1207-14.

20. Neveus T, Sillen U. Lower urinary tract function in childhood: normal development and common functional disturbances. Acta Physiol. (Oxf). 2013; 207 (1): 85-92.

21. Queiroz Machado V, Monteiro A, Pecanha A, Garcez da Foseca E. Slow transit constipation and lower urinary tract dysfunction. J Pediatr Urol. 2015; 11 (6): 3571-5.

22. Игнатьев Р. О., Гельд В. Г., Гусева Н. Б., Божендаев Т. Л. Диагностика нарушений мочеиспускания у детей: все ли делаем правильно? Российский вестник детской хирургии, 


\section{OPINION I UROLOGY}

анестезиологии и реаниматологии. 2014; 4 (3): 39-45.

23. Nurko S, Scott SM. Coexistence of constipation and incontinence in children and adults. Best Pract Res Clin Gastroenterol. 2011; 25 (1): 29-41.

24. Нестеренко О. В., Горемыкин В. И. Комплексный подход к лечению первичного моносимптомного ночного энуреза у детей. Лечащий врач. 2013; (9): 70-3.

25. Захарова И. Н., Мумладзе Э. Б., Пшеничникова И. И. Энурез в практике педиатра. Медицинский совет. 2017; (1): 172-9.

26. Морозов В. И., Аюпова В. А., Салихова Л. Т. Лечение различных клинических форм энуреза у детей. Практическая медицина. 2016; 7 (99): 77-80.

27. Никитин С. С., Игнатьев Р. О., Гусева Н. Б., Рыжов Е. А., Фоменко О. Ю., Пономарева Т. Н. Возможности повышения качества жизни детей с сочетанными расстройствами мочеиспускания и дефекации при унификации методов диагностики и лечения. Детская хирургия. 2014; (5): 8-12.

28. Беляева Н. А., Шматок Д. О., Блинов Е. В., Гулиев А. Г. Игуменов И. А., Теричев А. Е. Опыт применения биологической обратной связи в лечении детей с различными видами энуреза. Здоровье и образование в XXI веке. 2016; 18 (11): 21-3.

29. Ebilogiu T, Kaya E, Körpü B, Topuz B, Irkilata HC, Kibar Y Biofeedback as a first-line treatment for overactive bladder syndrome refractory to standard urotherapy in children. J Pediatr Urol. 2016; 12 (5): 2901-7.

30. Sansak EB, Akbaș A, Kurt Ö, Alan C, Ersay A R. The effectiveness of biofeedback therapy in children with monosymptomatic enuresis resistant to desmopressin treatment. 2016; 41 (4): 278-84. 